Article

\title{
Reimagining a Transnational Right to the City: No Border Actions and Commoning Practices in Thessaloniki
}

\author{
Charalampos Tsavdaroglou \\ Department of Planning and Regional Development, University of Thessaly, 38334 Volos, Greece; \\ E-Mail: tsavdaroglou.ch@gmail.com
}

Submitted: 15 January 2019 | Accepted: 29 March 2019 | Published: 27 June 2019

\begin{abstract}
Although there is extensive literature on State migration policies and NGO activities, there are few studies on the common struggles between refugees and local activists. This article aims to fill this research gap by focusing on the impact of the transnational No Border camp that took place in Thessaloniki in 2016. The border region of northern Greece, with its capital Thessaloniki, is at the heart of the so-called refugee crisis and it is marked by a large number of solidarity initiatives. After the sealing of the "Balkan corridor", the Greek State relocated thousands of refugees into isolated and inappropriate camps on the outskirts of Thessaloniki. Numerous local and international initiatives, with the participation of refugees from the camps, self-organized a transnational No Border camp in the city center that challenged State policies. By claiming the right to the city, activists from all over Europe, together with refugees, built direct-democratic assemblies and organized a multitude of direct actions, demonstrations, and squats that marked the city's social body with spatial disobedience and transnational commoning practices. Here, activism emerges as an important field of research and this article aims to contribute to activists' literature on migration studies after 2015. The article is based on militant research and inspired by the Lefebvrian right to the city, the autonomy of migration, and common space approaches. The right to the city refers to the rights to freedom, socialization, and habitation, but also to the right to reinvent and change the city. It was recently enhanced by approaches on common spaces and the way these highlight the production of spaces based on solidarity, mutual help, common care, and direct democracy. The main findings of this study point to how the struggle of migrants when crossing physical and social borders inspires local solidarity movements for global networking and opens up new possibilities to reimagine and reinvent transnational common spaces.
\end{abstract}

\section{Keywords}

commons; No Border camp; refugees; right to the city; Thessaloniki

\section{Issue}

This article is part of the issue "The European Refugee Controversy: Civil Solidarity, Cultural Imaginaries and Political Change", edited by Gert Verschraegen (University of Antwerp, Belgium) and Robin Vandevoordt (University of Oxford, UK/University of Antwerp, Belgium).

(C) 2019 by the author; licensee Cogitatio (Lisbon, Portugal). This article is licensed under a Creative Commons Attribution 4.0 International License (CC BY).

\section{Introduction}

Political actions and collective projects that took place in Greece before and during the first years of the so-called "economic crisis" are well known and have been thoroughly examined (Arampatzi, 2017; Daskalaki \& Kokkinidis, 2017; Karaliotas, 2017; Tsavdaroglou, Petrakos, \& Makrygianni, 2017). However, apart from a few studies mostly on the cases of Athens (Lafazani, 2018; Oikonomakis, 2018; Squire, 2018), the island of
Lesvos (Papataxiarchis, 2016; Vradis, Papada, Painter, \& Papoutsi, 2019), and Idomeni (Anastasiadou, Marvakis, Mezidou, \& Speer, 2018), little attention has been paid to emergent activists' struggles in Thessaloniki since 2015, during what has come to be known as the "refugee crisis". During this period there has been a kind of renewed political awareness, inspired and motivated by solidarity with the refugees who were crossing Greece that gave way to new political collectives and numerous refugee solidarity initiatives. 
Even though there is a plethora of studies and published papers on State migration policies, social charity and NGO actions (Gabiam, 2012; Ihlen, Figenschou, \& Larsen, 2015; Rozakou, 2017), as well as on arrival cities (Saunders, 2010; Taubenböck, Kraff, \& Wurm, 2018), sanctuary cities (Darling, 2009; Roy, 2019), and the broader issue of refugees and the city (Hatziprokopiou, Frangopoulos, \& Montagna, 2016; Sanyal, 2012), there is a lack of studies examining common struggles of locals and refugees and the ways these can re-shape local movements and re-invent new fields of social and political intervention. This article explores the above issues, inspired by the Lefebvrian notion of "the right to the city" and the approaches on "common space" and "autonomy of migration". According to Lefebvre (1968/1996), the notion of the right to the city is a superior right that includes the rights to freedom, socialization, and habitation while several scholars (Dikeç, 2002; Harvey, 2012; Marcuse, 2009; Mayer, 2009; Mitchell, 2003;) emphasize that the right to the city is not just a juridical claim but also a right of every resident to reinvent and change the city. The notion of the right to the city has been recently supplemented by approaches on common space (Dellenbaugh, Kip, Majken, Muller, \& Schwegmann, 2015; Tsavdaroglou, 2018; Stavrides, 2015) that stress the potentiality of the creation of self-organized urban spaces based on the principles of solidarity and direct democracy. Focusing here on the refugees' struggles for the right to the city, we can link the approaches on common spaces and the right to the city with the theory of autonomy of migration (Casas-Cortes, Cobarrubias, \& Pickles, 2015; Mezzadra \& Neilson, 2013; Nyers, 2015), which highlights the agency of migrants and refugees against the dominant State and hyper-State controlling and policing structures.

Thessaloniki, Greece's second largest city, is an interesting case study to explore such concerns as there is an ongoing spatial, social, and political conflict over the refugees' right to housing and to the city. During 2015-2016, we witnessed a massive movement of refugees from the conflicted areas of the Middle East, Asia, and North Africa heading mainly to North Europe. The main route followed was the Balkan corridor in South-eastern Europe and the city of Thessaloniki, as it is located in northern Greece near the border with North Macedonia, is an important hub in this journey. According to UNHCR (2016), from July 2015 to March 2016 about 777.487 refugees crossed the northern border of Idomeni and arrived in North Macedonia, most of them from Syria (55\%), Iraq (26\%), and Afghanistan $(15 \%)$ and the remaining (4\%) representing other nationalities such as Iranians, Palestinians, Pakistanis, Somalis, Congolese, and Bangladeshi. Idomeni, a small village with 154 residents (Hellenic Statistical Authority, 2011) located at the northern border of Greece with North Macedonia, is around 70km from Thessaloniki. In March 2016, following the Euro-Turkish statement (European Council, 2016) that aimed "to end the irregular migra- tion from Turkey to the EU", the Balkan countries and Macedonia sealed their borders. In the borderscape of Idomeni, there was already a makeshift settlement with about 20,000 refugees who were relocated in the summer of 2016 to 13 State-run camps on the perimeter of Thessaloniki. The State-run camps were organized in old factories and military bases within industrial zones in extremely polluted and dangerous areas, with poor facilities and services for shelter, safety, food, health, education, and psychological support. At the same time, a diverse body of local and international activists with leftist and anarchist backgrounds and a multitude of solidary people that mobilized primarily in Idomeni and in State-run camps provided autonomously organized housing structures to refugees in Thessaloniki and later organized the transnational No Border Camp in the summer of 2016.

The structure of the article is as follows. The second part presents the methodological approach of militant ethnographic research. The third examines the theoretical approaches to the right to the city and how it can be enriched through the literature on commons and autonomy of migration. The following two parts examine the particular features of the emerging refugee housing commons in Thessaloniki between 2015 and 2016 and the No Border Camp that took place in Thessaloniki in the summer of 2016 as well as the repressive policies of the "yes border" authorities. Finally, the article ends with some concluding thoughts on how to reimagine a transnational "no border" right to the city of commons.

\section{Methodology}

The article is based on participatory observation and militant ethnographic research. I draw particular attention to the call of De Genova (2010, p. 11) for "a genuinely critical scholarship of migration" that " must in fact be addressed to the task not merely of describing but also theorizing...actual struggles, the real social relations of unresolved antagonism and open-ended struggle that continuously constitute social life". In order to reflect on and theorize the examined struggles, I follow the methodology of militant ethnography (Bookchin et al., 2013; Colectivo Situaciones, 2003) that "seeks to overcome the divide between research and practice" (Juris, 2007, p. 165). Although similar methodologies like "participatory action research" (Cameron \& Gibson, 2005; Kindon, Pain, \& Kesby, 2007) and "scholar activism" (Chatterton, Hodkinson, \& Pickerill, 2010; Derickson \& Routledge, 2015) examine the interaction between academia and activism, they remain within the academic production. Yet, militant research aims to produce "politically applicable knowledge from within movements, for movements" (Apoifis, 2017, p. 5) and as Shukaitis, Graeber and Biddle (2007, p. 9) claim, militant research is "not a specialized task, a process that only involves those who are traditionally thought of as researchers. It is an intensification and deepening of the political". Along this process, it is im- 
portant to acknowledge the researcher's own positions and privileges as a white middle-class man, and the potentiality of repositions through emergent coexistences with refugees.

The study is based on 30 semi-structured interviews with refugees from Syria, Iraq, Morocco, Algeria, Iran, and Afghanistan and activists from Greece, Germany, and Spain. Most interviews lasted between one to two hours and took place in Thessaloniki during the days of the summer 2016 No Border camp, while further interviews followed the next couple of years. Half of the participants self-identified as male, $45 \%$ as female, and $5 \%$ as queer and transgender. Most of the participants were graduates of higher education or university students. The interviews were conducted in Greek and English and some were translated from Arabic and Farsi into English. The article is further based on the discourse analysis of material texts, manifestos, and posters of activists' campaigns in order to examine stated goals and objectives. It should be noted that the names of the participants in the research, refugees, and solidarity activists have been changed in order to protect their anonymity and replaced by culturally appropriate names that maintain the liveliness of personal narration.

\section{Commoning Practices for the Right to the City and Autonomy of Migration Approach}

The point of departure for the discussion on the right to the city is Henri Lefebvre's homonymous work, which was published 100 years after Marx's Capital and a few months before May 1968. This was a period of various emergent movements addressing political and social rights for workers, students, women, people of color, homosexuals, the right to freedom of speech, and environmental issues. In this historical context, Lefebvre aims not only to understand the city but also the social relationships that can change it. As he stresses:

The city [is] a projection of society on the ground that is, not only on the actual site, but at a specific level, perceived and conceived by thought...the city [is] the place of confrontations and of (conflictual) relations..., the city [is] the 'site of desire'....and site of revolutions'. (Lefebvre, 1968/1996, p. 109)

Lefebvre defines the right to the city as follows:

The right to the city manifests itself as a superior form of rights: the right to freedom, to individualization in socialization, to habitat and to inhabit. The right to the oeuvre, to participation and appropriation (clearly distinct from the right to property), are implied in the right to the city. (Lefebvre, 1968/1996, pp. 173-174)

The above definition of the right to the city is extremely important here as it highlights the following features: freedom, individuality through collectivity, the concepts of "habitation" and "inhabitation", the notion of "oeuvre" (work) as a participatory activity and the concept of "appropriation" against private property. The critical point in Lefebvre's formulation is the "socialization", or collective meeting as a necessary condition for freedom. In addition to socialization comes the "participatory activity", which produces the city as a collective "oeuvre" of the actions of the associated subjects-inhabitants.

Lefebvre's work has inspired a number of scholars and thinkers and continues to expand its influence and extend in multiple directions. For example, Harvey (2012) identifies the question of "what kind of city we want" with the question of "what kind of people we want to be, what kinds of social relations we seek, what relations to nature we cherish, what style of life we desire, what aesthetic values we hold" (Harvey, 2012, p. 4). Therefore, the right to the city becomes "far more than a right of individual or group access to the resources that the city embodies: it is a right to change and reinvent the city more after our hearts' desire" (Harvey, 2012, p. 4). Furthermore, Mitchell (2003) insightfully comments that the most important point in the right to the city is "the right to inhabit the city-by different people and different groups" (Mitchell, 2003, p. 18), and how "new modes of inhabiting are invented" (Mitchell, 2003, p. 18). While Merrifield (2011) expands the previous argument and stresses that during metropolitanization and urban sprawling, particular attention should be paid not only to the right to the city but also to the Lefebvrian "right to centrality". In his words:

Not a simple visiting right...no tourist trip down memory lane, gawking at a gentrified old town, enjoying for the day a city you've been displaced from, but a right to participate in life at the core, to be in the heat of the action. (Merrifield, 2011, p. 475)

Moreover, Marcuse argues that the right to the city "is not meant as a legal claim enforceable through a judicial process today" (Marcuse, 2009, p. 192) and Mayer (2009, p. 367) claims that "it is less a juridical right, but rather an oppositional demand...it is a right that exists only as people appropriate it (and the city)". In addition, Dikeç (2002) points out that the right to the city "implies not only a right to urban space but to a political space as well, with the participation of all city residents" and argues that this participation concerns the "resistance to the state" and "the very possibility of the formation of voices, of political subjectivization it generates in and around urban space" (Dikeç, 2002, p. 96). Finally, Purcell (2013a), in his reading of the Lefebvrian right to the city, draws particular attention to the concept of "autogestion" that refers to the way inhabitants come "to manage the production of urban space themselves" (Purcell, 2013a, p. 150).

Recently, the aforementioned approaches to the right to the city have been enriched by theories on urban commons and common spaces. The discussion on commons takes Hardin's (1968) "tragedy of the com- 
mons" as a reference point, which describes how a shared resource is in danger of being depleted when the users behave as selfish "free riders" and overuse it. As a solution to the overuse of common resources, free-market supporters propose privatization (Smith, 1981; Welch, 1983), while the supporters of State regulation (Ehrenfeld, 1972; Heilbroner, 1974) argue that the State is the best guarantor for the protection and regulation of efficient use of common pool resources. Beyond this binary, Ostrom's (1990) approach, based on the study of a rich variety of common pool resources and natural resource management across the globe, argues that producers' communities are able to self-organize and achieve effective economic outcomes. While the discourse on urban commons and common spaces has further highlighted that, beyond the logic of the State and the market, it is possible to produce spaces based on solidarity, mutual help, common care, and direct democracy following the long tradition of autonomous Marxism (Dellenbaugh et al., 2015; Stavrides, 2014; Tsavdaroglou, 2018). According to Chatterton, Featherstone and Routledge (2013, p. 610), the common "refers to the social process of being-in-common, a social relationship of the commoners who build, defend, and reproduce the commons". Moreover, Caffentzis and Federici (2014) emphasize the political character of the commons as a continuous social struggle; in their words, "commons are not only the means by which we share in an egalitarian manner the resources we produce" but "a commitment to fostering common interests in every aspect of our life" (Caffentzis \& Federici, 2014, p. 103). As they stress, "no struggle will succeed in changing the world if we do not organize our reproduction in a communal way...and the rejection of all principles of exclusion or hierarchization" (Caffentzis \& Federici, 2014, p. 103). At the same time, the right to the city enriches the discussion on commons. As outlined by Stavrides (An Architektur, 2010, p. 17), the right to the city "can be produced through encounters that make room for new meanings, new values, new dreams, new collective experiences. And this is indeed a way to transcend pure utility, a way to see commons beyond the utilitarian horizon". The crucial point in Stavrides' work is that the city of common emerges between "thresholds", which are "open to use, open to newcomers" (Stavrides, 2014, p. 548). This is particularly important, as it describes the interaction of local movements with newly arrived refugees. According to Stavrides (2014, p. 547), "thresholds explicitly symbolize the potentiality of sharing by establishing intermediary areas of crossing, by opening the inside to the outside". The refugee housing squats and the No Border camp depict a city as an open threshold to newcomers.

The discussed theoretical background shapes a fertile field for exploring the connections between the right to the city, commons, and the approach of "autonomy of migration". The scholars of "autonomy of migration" (Casas-Cortes et al., 2015; Mezzadra \& Neilson, 2013; Nyers, 2015) seek to untie the discussion on migration from the dominant (State and hyper-State) structures of control, policing, and regulation, and highlight the power activities of migrants-agents who are struggling to cross the multiple physical, social, and political borders. This points to the so-called "mobile commons" (Papadopoulos \& Tsianos, 2013; Trimikliniotis, Parsanoglou, \& Tsianos, 2015) the forms of commoning among moving populations and interactions with solidary people. Although mobile commons refer to the potentialities of mobile populations to selforganize and develop political and social struggles, they often acquire features of spatial disobedience. In the case of Thessaloniki and the housing squats and No Border camp, the emergent forms of socio-political struggles self-organized by mobile populations and solidarity activists and materialized in the urban fabric reveal the amalgamation of features of mobile and urban commons.

\section{Inventing Transnational Housing Commons}

Since autumn 2015 a multitude of actions has taken place in solidarity with refugees who have crossed mainland Greece trying to reach Idomeni, the northern border of the country with North Macedonia. Solidarity actions peaked when the borders closed and Idomeni's makeshift settlement started to take shape (Anastasiadou et al., 2018). In response to the State's threats of the evacuation of Idomeni's settlement, the first squat-housing project was organized in an abandoned building, an old Orphanage (Orfanotrofio in Greek) in Thessaloniki. The self-organized housing squat of Orfanotrofio, as well as the others that followed, were located in the center of the city. In contrast, State authorities relocated the refugees to 13 camps on the perimeter of Thessaloniki after the sealing of the GreekMacedonian borders.

The State-run camps are former factory spaces and old military bases which do not follow international and national standards for the refugees' right to the city and to housing (European Council on Refugees and Exiles, 2005; Presidential Decree, 2007). According to several reports (Amnesty International, 2016; International Rescue Committee, 2016), there is a critical lack of adequate services for health, education, child-care, psychological support, protection, and safety for single women and LGBTQ people. Moreover, State-run camps are located in industrial zones, environmentally degraded and hazardous areas, with a weak transport connection to the city center (see Figure 1). This tends to make refugees invisible and forces them to live in extremely precarious conditions.

In contrast to the State policies that exclude refugees on the perimeter of the city, the housing project of Orfanotrofio, which hosted more than 100 refugees, was created in the city center, experimenting with the coexistence of different populations and the creation of a transnational social center for housing and struggle. 


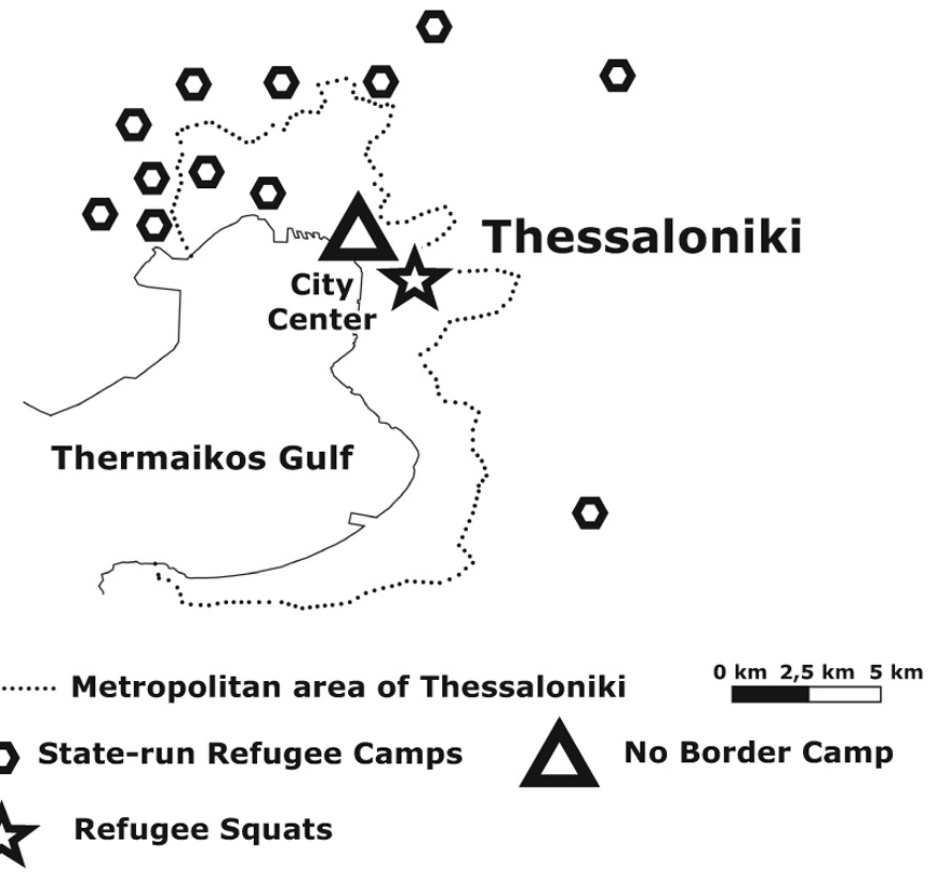

Figure 1. Location of State-run camps, refugee squats and No Border camp. Source: author.

It is especially important that the refugees in the housing project of Orfanotrofio met political groups and local residents and created a new political movement. In line with Dikeç (2002), this demonstrates that the right to the city is not only a right to the physical urban space but also a right to political space. In the words of Panagiotis, a member of the squat assembly, "against the police-military management of the migration, we do not just want to build a home, but our goal is to make Orfanotrofio a center of struggle" (Personal interview, March 15, 2018). This resonates with Purcell's (2013b, pp. 566-567) argument that "the act of inhabiting the city must be the basis for making claims on it". As Maria, another member of the squat assembly emphasized, "we wanted to create visibility for the refugees, to be in the city, to be in relation to the city, we wanted our struggles to be in common; we wanted to have common demands and we did" (Personal interview, September 23, 2016). It becomes clear that the creation of a common space is not just a claim to a physical space but also a process of organization of political struggle. Crucial to the development of a common political and social struggle according to Kostas, also a member of the squat assembly "is the difference between philanthropy and solidarity". He described: "in the first case, you believe that you are superior to the refugee, while in the second case, you try to become equal" (Personal interview, April 22, 2018). As the assembly of Orfanotrofio emphasized in an announcement:

We do not perceive ourselves as privileged in relation to the refugees and immigrants, but we are in a common position with them, against masters and nations.
We share all we have with them and we fight together. (Housing squat for immigrants Orfanotrofio, 2016a)

Particularly, as the founding proclamation of Orfanotrofio stressed, "we choose our actions to be collective and our words to be communicated, aiming at partnership and the development of communal relations" (Housing squat for immigrants Orfanotrofio, 2016b). In order to achieve this, the housing project was organized as a "socially open structure" and as the participants pointed out, "it was embraced by people of the broader radical movement (communists, anarchists, autonomists) and operated in a self-organized and anti-hierarchical way" (Housing squat for immigrants Orfanotrofio, 2016b). Occupation assemblies involved around 150 people and depicted a bold attempt to bridge political disputes. As members stated, "although we are an Orfanotrofio assembly formed by diverse people, we have managed to find and define common agreements and demands" (Housing squat for immigrants Orfanotrofio, 2016b). These claims concern "free movement and access to health for everyone, opposition to the Evros-river fence, and papers to all immigrants" (Housing squat for immigrants Orfanotrofio, 2016b).

The most important point in the operation of the squat is that the assembly was open and this openness made the project sustainable and feasible. However, openness does not mean the absence of rules. The transnational common space of Orfanotrofio squat was designed and crafted based on the principles of selforganization, anti-hierarchy, horizontal decision-making, and the explicit proclamation against any discrimination based on religion, ethnicity, and gender. Rizan, a 
Syrian refugee and member of the squat, remembers that "the rules of the squat were: no violence in any way; no distinction between different ethnicities or religions; sexist behaviors were not allowed; there was equality between men and women" (Personal interview, February 10, 2018). The negotiation of multiple identities was an issue of experimentation, as previous experiences of common action by the local movement and refugees were absent or sporadic. Hence, in this case, such challenges were grounded and tested in everyday life. As a statement from the organizing assembly of Orfanotrofio announced:

We want refugees in our neighborhoods, in our workplaces, in our homes, in our schools together with our children. We set up structures in our cities and in our neighborhoods as places of resistance and as places where our struggles meet with those of migrants because to struggle together, we must share our thoughts, our experiences, and our needs'. (Housing squat for immigrants Orfanotrofio, 2016d)

Consequently, the squat became the vehicle for claiming the right to the city, a right that was based on both equal access to public services and a collective and mutual struggle.

There were also several assemblies and solidarity structures created that provided food, clothes, and medical care. In addition, numerous political events, movie screenings, concerts, free bazaars, updates, and connections with refugee struggles from other parts of Greece and Europe took place. Moreover, actions against de- tention centers, solidarity actions in Idomeni, demonstrations in the center of the city, actions against racist and homophobic attacks, networking and coordination on pan-European days against the expulsion of immigrants and information events in other cities of Greece and Europe were organized (Housing squat for immigrants Orfanotrofio, 2016c). The most important is that this gave way to transnational proximity and a solidarity commoning which interacted with the neighborhood, with the local and the global. In the words of Fatima from Afghanistan:

I met lots of people, refugees, people in solidarity from Thessaloniki and abroad. I enjoyed this very much. I just made friends all the time. That was our life, it was not a life revolving around money and work; it was a life of friendship, sharing and struggle. Our lives had meaning. (Personal interview, February 13, 2018)

Other occupied social centers, such as Nikis, Fabrika Yfanet, and Libertatia followed the experience and political struggle above and accommodated refugees. While new housing squats were also created by solidary people and refugees in the city center such as Albatross, Turtle Corner, and Hurriya (see Figure 2). Thus, abandoned houses were occupied and transformed into transnational communal houses, claiming the right to the city, to housing, and to political struggle. But most importantly, the residents of these occupied houses lived a threshold experience, a condition that, according to Stavrides (2015, p. 12), "gives people the opportunity to share a
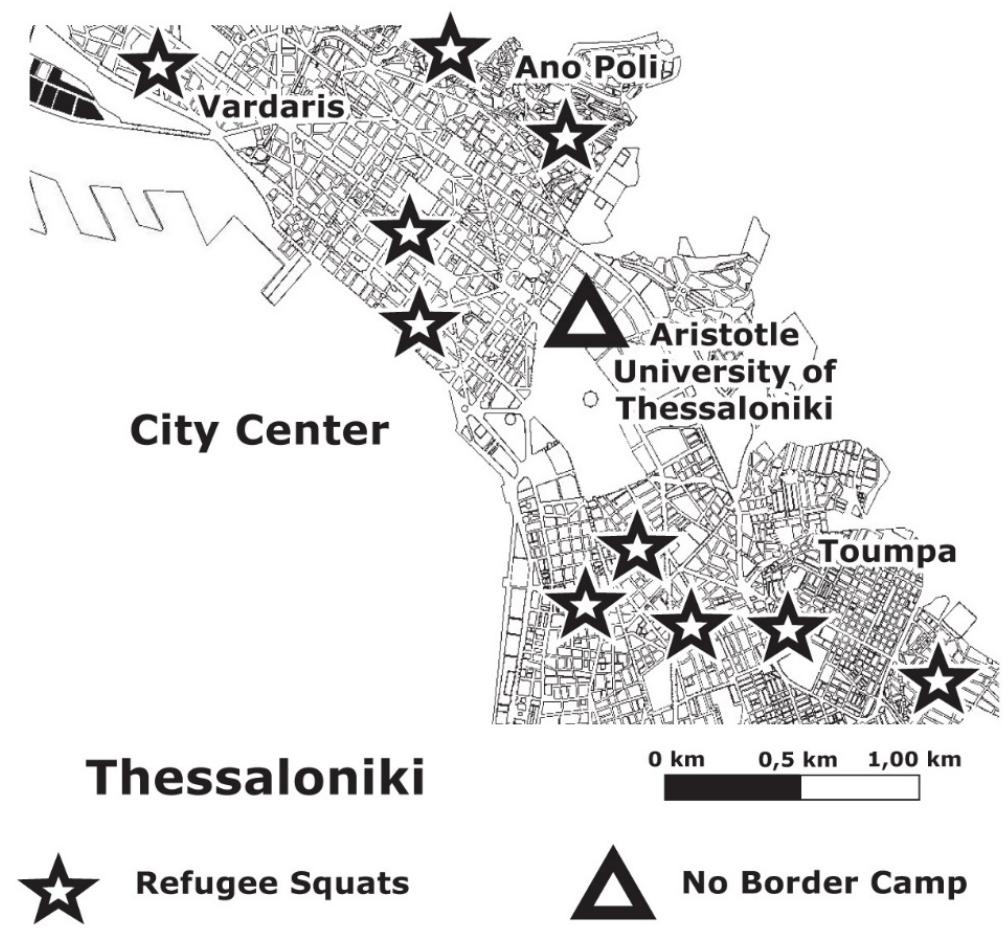

Figure 2. Location of refugee housing squats and No Border camp. Source: author. 
common world-in-the-making". Therefore, these structures can be seen as solidary gestures that invent, craft, and test the creation of transnational threshold common spaces.

\section{No Border versus Yes Border}

One of the most important processes in the Orfanotrofio squat was the assembly meetings for the transnational No Border camp that took place from July 15th to 24th of 2016. It is worth mentioning that the No Border camp emphasized three reasons for choosing the city of Thessaloniki. First, the city's position, as it is located "at the core of conflicts over the control and management of immigration and of the freedom of movement, due to its geographical position in northern Greece, bordering Albania, Macedonia and Bulgaria, with many detention camps...at its perimeter" (No Border Camp 2016 Organizing Assembly, 2016a, p. 4). Second, it enabled the creation of a variety of refugee solidarity initiatives and networks in northern Greece and in the Balkan region that could "be empowered and enhanced by the organization of a No Border camp" (No Border Camp 2016 Organizing Assembly, 2016a, p. 4). Third, Thessaloniki as a point of coordination for the aforementioned mobilizations and "its available grassroots infrastructures" seemed to "make the city a suitable and reliable choice for the organization of a global and transnational No Border Camp" (No Border Camp 2016 Organizing Assembly, $2016 a$, p. 4). Finally, the organizers of the No Border Camp underlined in their call that "meetings and struggles should be encouraged, should acquire steady and lasting structures and reinvent the joy and the charm of companionship and sharing" (No Border Camp 2016 Organizing Assembly, 2016a, pp. 3-4). Therefore, a gathering of solidarity initiatives, networking, and political awareness was proposed against the closing of borders.

The choices and practices of the No Border Camp constitute a political vision that corresponds to the Lefebvrian thought for an open city, for the right to the appropriation against private property and of participatory activity. In detail, the No Border Camp exhibited the following features:

First of all, the No Border Camp was established in the city center at the Aristotle University of Thessaloniki. This decision emphasizes the claim to the right to the city and highlights the Lefebvrian right to the center of the city. It appears to be in direct contrast to the State policies that place refugees in isolated camps on the outskirts of the city and exclude them from social and urban life. The No Border camp tried not only to occupy the physical center of the city, but also to provoke "existential" questions in the city's and country's central political sphere and to generate and reimagine an urban life based on non-discriminatory equality of access. These aspects revolve around Merrifield's (2011, p. 475) question, "isn't the right to centrality something internally generated, something existential, and not only geographical?"
Second, the No Border camp did not ask for legal permission from any authority but directly occupied the university's School of Law building and the surrounding park area. Hence, the right to the city is grounded here on the appropriation against the logic of private property, as the organizers of the No Border camp chose the open city and called for transnational networking and struggle against enclosures and fences, against borders and isolation. The commons emerge here in De Angelis's (2009) terms as a political struggle and open translocal spaces based on social relations.

Third, the No Border camp embraced and practiced participatory activity that transcends and transgresses the borders of ethnicity, religion, and gender. It is estimated that more than 3000 activists from all over Greece and other European and non-European countries gathered at the No Border camp for ten days. In addition, hundreds of refugees from State-run camps took part in events and actions.

During the No Border camp, more than fifty organized speeches were held that included topics related to refugee self-organization structures, State and hyperstate governmental policies for moving populations, gender aspects of immigration, and connections between the struggles of locals and refugees (No Border Camp 2016 Organizing Assembly, 2016b). Furthermore, during the ten days, a number of actions were organized, such as a massive demonstration in the city center, a demonstration against the State of emergency in Turkey, a demonstration against the fence in Evros river on GreekTurkish borders, and protests in State-run camps in the outskirts of Thessaloniki. The most important event, however, was the movement of hundreds of refugees from the isolated State-run camps around the city to the No Border camp. Families, children, and elderly refugees interacted with each other at a lively meeting, producing a multi-ethnic space. The refugees organized meetings, sang, danced, expressed their problems and discussed immigration policies in other European countries with foreign activists.

It has been argued that the interests and perspectives of activists are not necessarily the same as refugees' (Agustín, 2008; Rozakou, 2018). However, it seems that in periods of intense social and political struggles and emerging common spaces like the No Border Camp, the boundaries between locals and newcomers, refugees and Europeans, are destabilized. The No Border camp describes not just a campaign of privileged solidary people in the name of refugees, but a shared physical and social space where decisions, actions, and daily life was co-organized by the commoners -refugees and activists. It created a multiplicity of affective and solidary interactions where the participants negotiated different identities and shaped a sense of togetherness. The manner in which the No border camp experimented with nascent threshold spaces is crucial because they are valuable in generating and nurturing, as Stavrides (2015, p. 12) notes, "a kind of equalising potentiality". 
In the words of the Syrian refugee Mehdi:

During the No Border Camp, I met solidary people from many countries. I was very impressed as people from very distant countries came to support us. I felt that all the solidary people were standing with me. When I shouted the slogan "open the borders", I felt that there were all those solidary people standing with me, next to me and supporting me. This strong voice from all the demonstrators was very encouraging, it was like they felt what I felt. Especially, the great demonstration in the center of Thessaloniki was very important, because in addition to the protesters, I saw in the eyes of the people on the road that we are welcome. (Personal interview, November 23, 2017)

This transnational community that claimed the right to the city and to visibility seemed at first to surprise the city authorities. The State began to see what it was afraid of, the political association of refugees with the local and global movement. The response of the State came the day after the No Border Camp, when police forces evacuated three refugee squats in the center of the city at six in the morning. In the words of the No Border Camp organizers, "it was made perfectly clear that practical solidarity and communities of struggle where locals and migrants fight together are most threatening for the authorities and the dominant order" (No Border Camp 2016 Organizing Assembly, 2017, p. 83).

However, the criminalization of solidarity did not discourage political awareness and over the following months, a number of solidarity actions took place in the State-run refugee camps, generating fruitful transnational personal relationships and new struggling communities. As a result of the refugees' and activists' struggles and the publicity of the conditions in refugee camps, most of the State-run camps in the perimeter of the city were closed over the following year and UNHCR set up the REACT-Refugees Assistance Collaboration in Thessaloniki (2016), a program for hosting refugees in rented apartments in urban areas. Although similar programs were run in other parts of Greece, Thessaloniki was the only case with a remarkable reduction in the number of State-run camps. Less than a year after the No Border Camp was established, the 13 refugee camps documented in July 2016 with 18.222 refugees were reduced to 4 camps with 1.430 refugees in April 2017 (Coordination Centre for the Management of Refugee Crisis in Greece, 2016, 2017). Moreover, the experience of the No Border Camp triggered the recomposition of the activist body, the setting up of new transnational political groups, and the strengthening of anti-racist actions against future xenophobic and fascist attacks.

\section{Conclusions}

The refugee squats and the organization of the No Border Camp reveal that it is possible to create a transnational common space that crosses borders shaped by ethnic, religious, gender, and cultural classifications. Refugees and solidary people expressed the ability to reimagine, reinvent, and reclaim a transnational right to the city of commons. Aiming to enhance critical scholarship, I would like to emphasize five crucial arguments:

First, refugees' movement across natural, social, and political borders inspired a number of political collectives and individuals to come together, to coordinate, to negotiate their internal political disagreements, to try to overcome their internal political borders, and to discover the joy of togetherness. Groups of refugees, anarchist political organizations, health workers, self-organized trade unions, met for the first time. In local movement, it is rare that such a political recomposition takes place that highlights a valuable political heritage.

Second, the very subject of the political struggle was altered as it was untied from the narrow context of the Greek or European citizenship and transformed into a multinational concern that could spring from the Middle East war zones to the northern European countries. A multinational struggle that can, as shown, bring people from all over the world and reinvent a culture of coexistence through sharing, commoning, and struggling practices.

Third, the No Border camp and refugees' housing squats were social laboratories in which new forms of social relations emerged which pollinated the values of solidarity, caring, and collective struggle. These experiences enrich the discourse of the Lefebvrian right to the city, as a right to inhabit, to appropriation against private property, to freedom of movement and movement of freedom (according to the famous No Border camp slogan), to collectivization and participatory activity. The desire to change the city connects to transnational common spaces towards the production of a solidary city.

Fourth, the examination of the No Border camp and the housing squats highlights the importance of the notion of threshold in the creation of commons spaces. Against the social and spatial segregation of the Staterun refugee camps, activists decided to locate housing squats and the No Border camp in the very center of the city. Thus, both of these projects became social and political thresholds and functioned as bases for refugees to claim the right to the city.

Fifth, transnational meetings, participatory activities, and militant research problematize the European citizen's privileges and positionalities. Indeed, they can bring to the fore decolonial awareness and self-reflection beyond charitable and humanitarian structures, pointing to the potentialities for social change based on solidarity and equality that can form and reinvent transnational communities.

\section{Acknowledgments}

I would like to thank all the participants, refugees, and activists who contributed to the development of this 
work. Special thanks to Ilektra Kyriazidou for her useful comments. The scientific publication was carried out under the call for proposals "Invitation for participation of Doctoral Degree holders in Post-doctoral studies scholarship" of the University of Thessaly, which is being implemented by the University of Thessaly and was funded by the Stavros Niarchos Foundation.

\section{Conflict of Interests}

The author declares no conflict of interests.

\section{References}

Agustín, L. (2008). Sex and the limits of enlightenment: The irrationality of legal regimes to control prostitution. Sexuality Research \& Social Policy, 5. https:// doi.org/10.1525/srsp.2008.5.4.73

Amnesty International. (2016). Trapped in Greece: Refugees stranded in dire conditions as Europe drags its heels. Amnesty International. Retrieved from www.amnesty.org/en/latest/news/2016/07/trappedin-greece-48000-stranded-in-dire-conditions

An Architektur. (2010). On the commons: A public interview with Massimo De Angelis and Stavros Stavrides. e-flux, 17. Retrieved from https://www. e-flux.com/journal/17/67351/on-the-commonsa-public-interview-with-massimo-de-angelis-andstavros-stavrides

Anastasiadou, M., Marvakis, A., Mezidou, P., \& Speer, M. (2018). From transit hub to dead end. A chronicle of Idomeni. München: bordermonitoring.eu e.V.

Apoifis, N. (2017). Fieldwork in a furnace: Anarchists, anti-authoritarians and militant ethnography. Qualitative Research, 17(1), 3-19.

Arampatzi, A. (2017). The spatiality of counter-austerity politics in Athens, Greece: Emergent 'urban solidarity spaces'. Urban Studies, 54(9), 2155-2171.

Bookchin, N., Brown, P., Ebrahimian, S., Colectivo Enmedio, Junasz, A., Maartin, L., . . . Sitrin, M. (2013). Militant research handbook. New York, NY: NYU Steinhardt. Retrieved from http://www.visual culturenow.org/wp-content/uploads/2013/09/MRH _Web.pdf

Caffentzis, G., \& Federici, S. (2014). Commons against and beyond capitalism. Community Development Journal, 49(S1), i92-i105.

Cameron, J., \& Gibson, K. (2005). Participatory action research in a poststructuralist vein. Geoforum, 36(3), 315-331.

Casas-Cortes, M., Cobarrubias, S., \& Pickles, J. (2015). Riding routes and itinerant borders: Autonomy of migration and border externalization. Antipode, 47(4), 894-914.

Chatterton, P., Featherstone, D., \& Routledge, P. (2013). Articulating climate justice in Copenhagen: Antagonism, the commons, and solidarity. Antipode, 45(3), 602-620.
Chatterton, P., Hodkinson, S., \& Pickerill, J. (2010). Beyond scholar activism: Making strategic interventions inside and outside the neoliberal university. ACME, 9(2), 245-274.

Colectivo Situaciones. (2003). On the researcher-militant. EIPCP. Retrieved from http://eipcp.net/transversal/ 0406/colectivosituaciones/en

Coordination Centre for the Management of Refugee Crisis in Greece. (2016). Summary statement of refugee flows at 15.07.2016. Greece Media Gov. Retrieved from http://www.media.gov.gr

Coordination Centre for the Management of Refugee Crisis in Greece. (2017). Summary statement of refugee flows at 18.04.2017. Greece Media Gov. Retrieved from http://www.media.gov.gr

Darling, J. (2009). A city of sanctuary: The relational re-imagining of Sheffield's asylum politics. Transactions of the Institute of British Geographers, 35(1), 125-140.

Daskalaki, M., \& Kokkinidis, G. (2017). Organizing solidarity initiatives: A socio-spatial conceptualization of resistance. Organization Studies, 38(9), 1303-1325.

De Angelis, M. (2009). The tragedy of the capitalist commons. Turbulence. Retrieved from http://turbulence. org.uk/turbulence-5/capitalist-commons

De Genova, N. (2010). The queer politics of migration: Reflections on "illegality" and incorrigibility. Studies in Social Justice, 4(2), 101-126.

Dellenbaugh, M., Kip, M., Majken, B., Muller, A., \& Schwegmann, M. (Eds.). (2015). Urban commons: Moving beyond State and market. Basel: Birkhäuser Verlang.

Derickson, K., \& Routledge, P. (2015). Resourcing scholar-activism: Collaboration, transformation, and the production of knowledge. The Professional Geographer, 67(1), https://doi.org/10.1080/00330124. 2014.883958

Dikeç, M. (2002). Police, politics, and the right to the city. GeoJournal, 58, 91-98.

Ehrenfeld, D. (1972). Conserving life on earth. Oxford: Oxford University Press.

European Council. (2016). Press release: EU-Turkey statement, 18 March 2016. European Council. Retrieved from https://www.consilium.europa.eu/en/press/ press-releases/2016/03/18/eu-turkey-statement

European Council on Refugees and Exiles. (2005). The EC directive on the reception of asylum seekers: Are asylum seekers in Europe receiving material support and access to employment in accordance with European legislation? (AD3/11/2005/EXT/SH). Retrieved from https://www.refworld.org/docid/43f46eba4.html

Gabiam, N. (2012). When "humanitarianism" becomes "development": The politics of international aid in Syria's Palestinian refugee camps. American Anthropologist, 114(1), 95-107.

Hardin, G. (1968). The tragedy of the commons. Science, New Series, 162(3859), 1243-1248.

Harvey, D. (2012). Rebel cities: From the right to the city 
to the urban revolution. London: Verso.

Hatziprokopiou, P., Frangopoulos, Y., \& Montagna, N. (2016). Migration and the city. City, 20(1), 52-60.

Heilbroner, L. R. (1974). An inquiry into the human prospect. New York, NY: Norton.

Hellenic Statistical Authority. (2011). Announcement of the revision of the results of the 2011 population and housing census for the resident, de jure (registered) and de facto population of Greece. Hellenic Statistical Authority. Retrieved from http://www. statistics.gr/documents/20181/1210503/FEK_ monimos_rev.pdf/125204a0-726f-46fe-a141302d9e7a38dc

Housing squat for immigrants Orfanotrofio. (2016a). The first announcement for the eviction of housing squat for immigrants Orfanotrofio [Facebook post]. Retrieved from https://www.facebook.com/ katalipsistegismetanastonorfanotrofeio

Housing squat for immigrants Orfanotrofio. (2016b). We occupy the abandoned building of Orfanotrofio [Facebook post]. Retrieved from https://www.facebook. com/katalipsistegismetanastonorfanotrofeio

Housing squat for immigrants Orfanotrofio. (2016c). Who are we [Facebook post]. Retrieved from https://www.facebook.com/ katalipsistegismetanastonorfanotrofeio

Housing squat for immigrants Orfanotrofio. (2016d). End detention now. Migration is not a crime [Facebook post]. Retrieved from https://www.facebook.com/ katalipsistegismetanastonorfanotrofeio

Ihlen, Ø., Figenschou, T. U., \& Larsen, A. G. (2015). Behind the framing scenes: Challenges and opportunities for NGOs and authorities framing irregular immigration. American Behavioral Scientist, 59(7), 822-838.

International Rescue Committee. (2016). IRC deeply concerned over poor humanitarian standards at refugee transit sites in Greece. International Rescue Committee. Retrieved from http://www.rescue.org/blog/ refugee-crisis-latest-updates-storify

Juris, J. S. (2007). Practicing militant ethnography with the movement for global resistance in Barcelona. In S. Shukaitis, D. Graeber, \& E. Biddle (Eds.), Constituent imagination: Militant investigations, collective theorization (pp. 164-178). Edinburgh: AK Press.

Karaliotas, L. (2017). Staging equality in Greek squares: Hybrid spaces of political subjectification. International Journal of Urban and Regional Research, 41(1), 54-69.

Kindon, S., Pain, R., \& Kesby, M. (2007). Participatory action research approaches and methods: Connecting people, participation and place. London: Routledge.

Lafazani, O. (2018). Homeplace Plaza: Challenging the border between host and hosted. South Atlantic Quarterly, 117(4), 896-904.

Lefebvre, H. (1996). Writings on cities. Oxford: Blackwell. (Original work published 1968)

Marcuse, P. (2009). From critical urban theory to the right to the city. City, 13(2/3), 185-197.
Mayer, M. (2009). The "right to the city" in the context of shifting mottos of urban social movements. City, 13(2/3), 362-374.

Merrifield, A. (2011). The right to the city and beyond. City, 15(3/4), 473-481.

Mezzadra, S., \& Neilson, B. (2013). Border as method, or, the multiplication of labour. Durham, NC: Duke University Press.

Mitchell, D. (2003). The right to the city. Social justice and the fight for public space. New York, NY: The Guilford Press.

No Border Camp 2016 Organizing Assembly. (2016a). No Border Camp July 15-24 2016 Thessaloniki (Greece): For the circulation of transnational struggles against state, nationalism, patriarchy and capital. ThessaIoniki: No Border Camp Press. Retrieved from https:// noborder2016.espivblogs.net/files/2016/04/NoBorder-Camp-2016_en-1.pdf

No Border Camp 2016 Organizing Assembly. (2016b). Program. No Border 2016. Retrieved from https:// noborder2016.espivblogs.net/programme

No Border Camp 2016 Organizing Assembly. (2017). The Thessaloniki No Border Camp in retrospect. In Thessaloniki No Border Camp Press Team (Ed.), A collection of texts presented at the Thessaloniki No Border Camp (July 15-24, 2016) (pp. 83-86). Thessaloniki: No Border Camp Press.

Nyers, P. (2015). Migrant citizenships and autonomous mobilities. Migration, Mobility, \& Displacement, 1(1), 23-39.

Oikonomakis, L. (2018). Solidarity in transition: The case of Greece. In D. della Porta (Ed.), Solidarity mobilizations in the 'refugee crisis'. Contentious moves (pp. 65-98). Basingstoke: Palgrave McMillan.

Ostrom, E. (1990). Governing the commons: The evolution of institutions for collective action. Cambridge: Cambridge University Press.

Papadopoulos, D., \& Tsianos, V. (2013). After citizenship: Autonomy of migration, organisational ontology and mobile commons. Citizenship Studies, 17(2), 178-196.

Papataxiarchis, E. (2016). Being "there": At the front line of the "European refugee crisis". Part 1. Anthropology Today, 32(2), 5-9.

Presidential Decree. (2007). Transposing council directive 2003/9/EC from January 2003 laying down minimum standards for the reception of asylum seekers (Government Gazette Issue GG/251/A/13.11.2007). Athens: National Printing House.

Purcell, M. (2013a). Possible worlds: Henri Lefebvre and the right to the city. Journal of Urban Affairs, 36(1), 141-154.

Purcell, M. (2013b). To inhabit well: Counterhegemonic movements and the right to the city. Urban Geography, 34(4), 560-574.

REACT-Refugees Assistance Collaboration in Thessaloniki. (2016). City for refugees, support, cooperate, participate. REACT. Retrieved from https://www.react- 
thess.gr/react

Roy, A. (2019). The city in the age of Trumpism: From sanctuary to abolition. Environment and Planning D: Society and Space. https://doi.org/10.1177/ 0263775819830969

Rozakou, K. (2017). Solidarity \# humanitarianism: The blurred boundaries of humanitarianism in Greece. Etnofoor, 29(2), 99-104.

Rozakou, K. (2018). Solidarians in the land of Xenios Zeus: Migrant deportability and the radicalisation of solidarity. In D. Dalakoglou \& G. Agelopoulos (Eds), Critical times in Greece: Anthropological engagements with the crisis (pp. 188-201). New York, NY: Routledge.

Sanyal, R. (2012). Refugees and the city: An urban discussion. Geography Compass, 6(11), 633-644.

Saunders, D. (2010). Arrival city: The final migration and our next world. London: William Heinemann.

Shukaitis, S., Graeber, D., \& Biddle, E. (Eds.). (2007). Constituent imagination: Militant investigations, collective theorization. Edinburgh: AK Press.

Smith, R. J. (1981). Resolving the tragedy of the commons by creating private property rights in wildlife. CATO Journal, 1(2), 439-468.

Squire, V. (2018). Mobile solidarities and precariousness at City Plaza: Beyond vulnerable and disposable lives. Studies in Social Justice, 12(1), 111-132.

Stavrides, S. (2014). Emerging common spaces as a challenge to the city of crisis. City, 18(4/5), 546-550.

Stavrides, S. (2015). Common space as threshold space: Urban commoning in struggles to reappropriate public space. Footprint. Retrieved from https://journals.open.tudelft.nl/index.php/ footprint/article/view/896

Taubenböck, H., Kraff, N. J., \& Wurm, M. (2018). The morphology of the arrival city. A global categorization based on literature surveys and remotely sensed data. Applied Geography, 92, 150-167.

Trimikliniotis, N., Parsanoglou, D., \& Tsianos, V. (2015). Mobile commons, migrant digitalities and the right to the city. New York, NY: Palgrave MacMillan.

Tsavdaroglou, C. (2018). The newcomers' right to the common space: The case of Athens during the migrant crisis. ACME, 17(2), 376-401.

Tsavdaroglou, C., Petrakos, K., \& Makrygianni, V. (2017). The golden "salto mortale" in the era of crisis: Primitive accumulation and local and urban struggle in the case of Skouries gold mining in Greece. City, 21(3/4), 428-447.

UNHCR. (2016). FYR Macedonia inter-agency operational update 26 February-3 March 2016. UNHCR. Retrieved from https://data2.unhcr.org/es/ documents/download/47186

Vradis, A., Papada, E., Painter, J., \& Papoutsi, A. (2019). New borders. Hotspots and the European migration regime. London: Pluto Press.

Welch, W. P. (1983). The political feasibility of full ownership property rights: The case of pollution fisheries. Policy Sciences, 16(2), 165-180.

\section{About the Author}

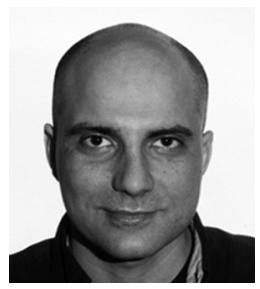

Charalampos Tsavdaroglou is a Postdoctoral Researcher of the Stavros Niarchos Foundation in the Department of Planning and Regional Development at the University of Thessaly, Greece. He holds a PhD in Urban and Regional Planning, School of Architecture, Aristotle University of Thessaloniki, Greece. His research interests include land grabbing, the right to the city, common space and urban social movements on which he has published several journal articles and book chapters in English and Greek. 